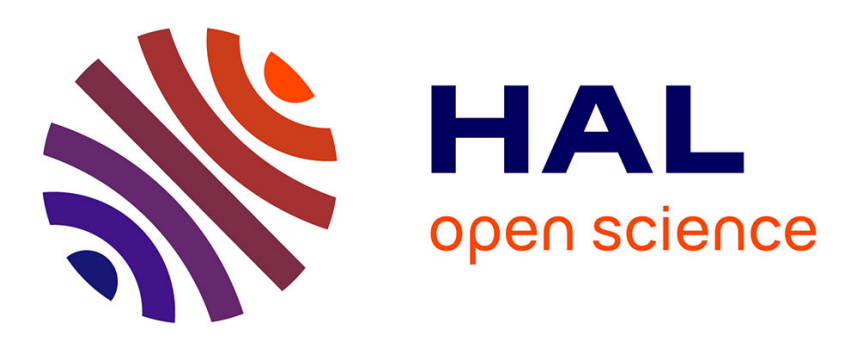

\title{
Everything you wanted to know about the Cenomanian (Cretaceous, 100.5-93.9 Ma)
}

Stéphane Peigne

\section{To cite this version:}

Stéphane Peigne. Everything you wanted to know about the Cenomanian (Cretaceous, 100.5-93.9 Ma). Cretaceous Research, 2016, 65, pp.32-33. 10.1016/j.cretres.2016.04.003 . hal-01311638

\section{HAL Id: hal-01311638 \\ https: / hal.sorbonne-universite.fr/hal-01311638}

Submitted on 4 May 2016

HAL is a multi-disciplinary open access archive for the deposit and dissemination of scientific research documents, whether they are published or not. The documents may come from teaching and research institutions in France or abroad, or from public or private research centers.
L'archive ouverte pluridisciplinaire HAL, est destinée au dépôt et à la diffusion de documents scientifiques de niveau recherche, publiés ou non, émanant des établissements d'enseignement et de recherche français ou étrangers, des laboratoires publics ou privés. 


\section{Book Review}

\section{Everything you wanted to know about the Cenomanian (Cretaceous, 100.5-93.9 Ma)}

\section{Stratotype Cénomanien}

Morel N. (coord.) 2015. Muséum national d'Histoire naturelle, Paris; Biotope, Mèze; 384 pp + 1 CD-ROM (Patrimoine géologique; 6). ISBN: 978-2-36662-156-5/978-2-85653775-6.

The city of Le Mans, and its surrounding region, is renowned well beyond the French border by its famous endurance motor races and perhaps also by its delicious rillettes (shredded pork pâté). The area is also appreciated by historians for its artistic and historical past, such as its long link with the Plantagenet lineage (Louis II, King of England and the father of Richard I, the Lionheart, was born in Le Mans!), or as being the country of the Aulerques Cenomans, the celtic tribe from which Le Mans derives its name. For geologists, this is a familiar toponym that inspired Alcide d'Orbigny to create the name Cenomanian, the earliest stage of the Upper Cretaceous and one of the fifty or so French stratotypes identified during the 19th and 20th centuries. This book proposes to describe the rich history of this geological stage. The Cenomanian is today an official stage of the International Geological Timescale; it is the basal stage of the Upper Cretaceous, spanning 6.6 million years. Its boundaries are clearly defined and dated by a Global Boundary Stratotype Section and Point (GSSP), which for the Albian-Cenomanian boundary is dated to $100.5 \mathrm{Ma}$, while that for the Cenomanian-Turonian is dated to 93.9 Ma.

Stratotype Cénomanien is the sixth volume in the book series entitled Patrimoine géologique edited by Patrick De Wever and Annie Cornée, from the French Muséum national d'Histoire naturelle. The book includes 384 pages, one dozen tables, and 274 exquisite sketches, maps, drawings, and photographs. I would have appreciated greater homogeneity in the figures (some are in color, some in black-and-white, and some use both), but this is a small detail. Current users of the series will find a familiar structure in the book. New readers of Stratotypes will appreciate its logical organization. A useful 
introduction recalls the notions of time in earth sciences, stratigraphy, and stratotypes, and briefly presents the position of the Cenomanian in the geological scale. The appendices, in particular, comprise the list of the institutions where collections are curated, and include a rich bibliography (374 references) and a helpful glossary. The five chapters that constitute the majority of the book present and analyse the history, geological context, and paleontological content (nearly half of the book!) of the Cenomanian, including descriptions of its relationships with the Iron Age, modern humans, and its patrimonial value.

The Cenomanian is, overall, a transgressive stage. Sea levels were much higher than today, with levels that have never been reached since. The stratigraphy of the Cenomanian includes a detailed description of the stratotypical Cenomanian formations; their geographic distribution is especially well illustrated. The paleogeography of Cenomanian deposits is described in detail also, with interesting isopach maps for the stratotypical area as well as for other areas of the Paris Basin (Anjou, Normandy, and Boulonnais). A part of this chapter is dedicated to the analysis of oceanic anoxia of the Cenomanian and their implications on the carbon cycle, faunas (extinction of a quarter of the marine invertebrate genera), and on the oil generation of today!

As a paleontologist, I read the paleontological content with particular interest. Fossils are illustrated by hundreds of photographs! The formations of Cenomanian stratotypical sites have yielded a rich (850 species) but heterogeneous assemblage of organisms: more than $40 \%$ of the taxa are molluscs, whereas $30 \%$ are foraminifera, bryozoans, or echinoderms. By contrast, vertebrates and plants are poorly represented. Probably due to their relevance to the Mesozoic stratigraphy in general and to that of the Cenomanian in particular, ammonites receive more attention than other taxa. These organisms are described in the most detail, by far, and are the best illustrated. Their paleobiology, fossilization, biostratigraphy, and biogeography, and detailed descriptions of ammonite faunas from the Cenomanian all receive extensive coverage. Unfortunately, bivalve molluscs, although being the richest taxon in the stratotype with 183 species, are not presented in much detail, except for oysters which are not particularly diversified (twenty species). Many of the taxa identified in stratotypical formations are known in other regions or Cenomanian sites not belonging to the stratotype (such as the case of the oysters, for example). Some fossils from the Cenomanian of Charentes, France 
(oysters, sea urchins) and Normandy (decapod crustaceans) are also described. These digressions concern only a few taxa, so the reader may question their relevance in the context of a book focused on a particular stratotype, but not on a whole geological stage. I have previously expressed such reserve for another book from the same series (Peigné 2014). The biodiversity of these stratotypical formations has original features though, which are worth noting. Some species are endemic to the Cenomanian stratotype or are very rare elsewhere, such as certain brachiopods, decapod crustaceans, and sea stars, and some taxa are exceptionally well preserved, such as the starfishes illustrated in Fig. 169. In addition, many amber sites are known and have yielded rarely preserved organisms (cyanobacteria, actinomycetes, complete arthropods). Microfossils, which are treated separately in the book, are diversified and dominated by a rich fauna of 95 species of foraminifera.

Books from the Patrimoine géologique series are not only for those fond of geology and/or paleontology. One of the merits of this collection is to expand the scope of the reader to the history and patrimonial dimension of a stratotype, which allows us to consider societal issues (natural heritage conservation, natural resource uses) in addition to more strictly scientific aspects. The goal of the fourth part of this book is to present the human uses of the Cenomanian deposits since the Iron Age. There is first the roussards sandstone from sandy ferruginous levels. As the name suggests, these sandstones have a reddish color characteristic of Le Mans itself (called the "Red City" by historians) and the surrounding region (the red Maine). These sandstones have been widely used as building material for major monuments (religious buildings, castles, bridge) as well as rural housing. The use and exploitation of the Cenomanian iron ore is older and concerns especially the area north of Le Mans. Many traces of extraction there (wells, pits), have also been discovered and excavated by archaeologists. Iron extraction dates back to the Iron Age ( $5^{\text {th }}$ century $\mathrm{BC}$ ) and was practiced until the early $20^{\text {th }}$ century.

The fifth and final part of Stratotype Cénomanien aims to make readers aware of the idea of geological heritage and to inspire us to protect it. The stratotype of the Cenomanian now includes a large number of sites across the Sarthe region, mainly near Le Mans. Many of the sites or outcrops studied in the $19^{\text {th }}$ and $20^{\text {th }}$ centuries are still accessible. Among them, fourteen are now subject to specific protection measures and 
allow access to most formations representing the Cenomanian in the region. All of these sites are described in detail and most are very well illustrated (geological section, photographs). The ex situ stratotypic heritage is also presented with qualitative (numbers of types and figured specimens) and quantitative descriptions of the stratotypical collections curated in French and foreign institutions.

Like other books in the Patrimoine géologique series, Stratotype Cénomanien is impressive in its exhaustive coverage. Readers will undoubtedly appreciate the rich iconography that makes the reading very enjoyable and the scientific content easier to understand for the non-specialist. The detailed tables of contents (one for general content and one for each of the five main chapters) reveal its impeccable organization. Stratotype Cénomanien is adapted to a wide audience: students in geology and paleontology, non-academics, as well as professionals, historians of science, and others. Some will look only at the book, whereas others in search of more detailed information, will enjoy the additional documentation provided by the accompanying CD-ROM. For example, it includes a full list of organisms discovered in the stratotypical Cenomanian deposits (850 species) and a list of types and figured specimens stored in the collections of the Musée Vert of Le Mans (nearly 600 pages!). Given its size, the quality of its iconography, and its rich content, Stratotype Cénomanien is both tremendously valuable and a great value. One regret, but which is not a true fault: it is written in French, which will unfortunately limit the dissemination of this work among non-French speaking colleagues.

\section{Reference}

Peigné, S., 2014. Everything you wanted to know about the Stampian (Oligocene, 33.928.1 Ma). Geobios 47, 345-346.

\section{Stéphane Peigné}

Centre de recherche sur la paléobiodiversité et les paléoenvironnements UMR 7207 CNRS/MNHN/UPMC

CP 38, 8 rue Buffon

75005 Paris, France peigne@mnhn.fr 